\title{
The Challenges of Adopting E-Governance in Iraq
}

\author{
THABIT H. THABIT ${ }^{1 *}$ and YASER A. JASIM ${ }^{2}$ \\ 'Department of Computer Engineering and Information, College of Electronics \\ Engineering, Ninevah University, Mosul, Iraq. \\ 2Department of Accounting, College of Administrative and Financial Sciences, \\ Cihan University - Erbil, Kurdistan Region, Iraq.
}

\begin{abstract}
One of the most important technology applications to monitor the effectiveness of e-government services in the current era is e-governance. E-governance monitors the quality of government services, the exchange of information, and the efficiency of institutional communications within the digital environment. The current paper aims to analyze the main challenges faced by adopting e-governance in Iraq as a developing country by analyzing the organization's potential strengths and possible weaknesses in addition to the opportunities and threats for adopting e-governance through using SWOT (Strengths, Weaknesses, Opportunities, and Threats analysis), and to evaluate main four aspects (politic, society, economy, and technology) of adopting the e-governance in digital environment through using PEST (Political, Economic, Socio-cultural and Technological analysis). The researchers find that the governmental organizations in Iraq are using the services of the Internet such as websites, social media site, and blogs to supply citizens with governmental services, but there is a huge gap among the four different aspects. The researchers conclude that the weaknesses of the e-governance applications adopted in Iraq should be recognized, the current threats must be eliminated, and practical solutions should be found to reduce the gap among the four aspects.
\end{abstract}

\section{Introduction}

The tremendous development of communication technologies and the digital exchange of information have helped the development of institutional communication and enhanced the orderly storage of data and increased the efficiency of feedback,

CONTACT Thabit H. Thabit thabit.thabit@ $@$ uoninevah.edu.iq 9 Department of Computer Engineering and Information, College of Electronics Engineering, Ninevah University, Mosul, Iraq.

\section{(c) (i)}

(C) 2019 The Author(s). Published by Enviro Research Publishers.

This is an Open Access article licensed under a Creative Commons license: Attribution 4.0 International (CC-BY).

Doi: http://dx.doi.org/10.12944/CRJSSH.2.1.04 
which led government organizations to provide their services electronically in order to reduce cost and increase speed in order to regularize services and raise the level of customer satisfaction.

The fundamental benefits of using digital environment tools have been transformed from data-processing tools accurately and rapidly to tools for data classification and information analysis to rationalize decision making in the organization.

The growth of Internet connectivity and cloud computing help citizens to modify their actions to be suitable for this technological development in order to obtain the highest level of facilities provided by the digital environment.

The adoption of digital environment by the government to provide its services contributed to the emergence of e-governance in order to instill confidence in electronic transactions, deepen the interdependence between citizens and governmental organizations, and participate in decision-making.

The term of e-governance is basically the application of electronic environment tools to control the performance of e-government in a simple, ethical, accountable and transparent manner to achieve the smart government.
The adopting of E-governance in developing countries such Iraq can be the main problem of this research due to the many challenges which can face it. So the main objective of the research is analyzing the main challenges faced by adopting e-governance in Iraq as a developing country using the organization's potential strengths and possible weaknesses in addition to the opportunities and threats for adopting e-governance through using SWOT, in addition to evaluate main four aspects (politic, society, economy, and technology) of adopting the e-governance in digital environment through using PEST.

\section{E-Governance Concept}

Governance, in general, is the administration activity which relates to the decisions that determine expectations, grant of authority, or verify of the performance, in other words, it strengthens the control of the activity of the organization and follows up the level of performance of provided services and increases the participation of citizens in monitoring the performance of the governmental organizations. ${ }^{1}$

So, governance varies according to the various types of organizations depending on the following conditions ${ }^{2}$ :

- Small governmental organization: the duty of governance can be receiving data, ensuring

Table 1: The Analyzing of the Political Aspect by SWOT

\begin{tabular}{|c|c|}
\hline Strengths & $\begin{array}{l}\text { - Combination with democratizationreforms } \\
\text { - Intemet as pull factor } \\
\text { - Modem image }\end{array}$ \\
\hline Weaknesses & $\begin{array}{l}\text { - } \text { Budget } \\
\text { - } \text { Cyberlaws not available } \\
\text { - No problem owner within govemment } \\
\text { - Slow decision making process } \\
\text { - } \\
\text { - Sierarchy in organizations } \\
\text { - Integration and reform }\end{array}$ \\
\hline Opportunities & $\begin{array}{l}\text { - Raise extemal funding } \\
\text { - Show competitive edge } \\
\text { - Transparency causes natural change of } \\
\text { processes } \\
\text { - Reinvent govemment }\end{array}$ \\
\hline Threats & $\begin{array}{l}\text { - } \text { Bureaucracy } \\
\text { - } \text { Piracy, misuse } \\
\text { - } \\
\text { - } \text { Maintaining disorder, no transparency } \\
\text { - } \\
\text { Pelitical instability } \\
\text { Resistance }\end{array}$ \\
\hline
\end{tabular}


its clearness, and ensuring its accuracy.

- Local organization: the duty of governance can be assessing the link between the administration of the organization and the employees.

- $\quad$ Big organization: the duty of governance can be showing the level of accountability to stakeholders and citizens.

So, the term of e-governance can be explained as the presentation of traditional governance through the electronic environment to organize data, show it rapidly and in clear shape, and perform the governmental actions well. ${ }^{3}$

UNESCO argues that e-governance can engage novel kinds of leadership, modern styles of investigations, new methods of decision making, novel tools to enhance the management education, and fresh ways to arrange data. ${ }^{4}$

The European Council introduces three areas to use e-governance in public activities 5 :

- The relationships between the internal environment of the organization and its external environment.

- The achievement of e-democracy by managing the internal environment of the organization at all levels of internal activities

- $\quad$ The management control of public services electronically

\section{E-Governance Stages}

However, modern technologies have been available in Iraq recently, especially after the liberalization of the Iraqi economy in the early 21 st century. The adoption of e-governance has started in the following stages $^{6}$ :

- $\quad$ Computerization: In the first stage a big amount of governmental offices got prepared with computers and electrical systems. The using of these systems started with word processing, rapidly followed by information processing.

Networking: Some departments of a little government organizations got linked throughout a hub which leads to distribute and share of data and flow of information among various government departments.

- On-line attendance: With the raising of Internet connectivity, a request was suffered for keeping an attendance on the web. This created a keeping of websites by government units and other departments. Basically, these

Table 2: The Analyzing of the Social Aspect by SWOT

\begin{tabular}{|c|c|}
\hline Strengths & $\begin{array}{l}\text { - People eager to leam } \\
\text { - IT skills } \\
\text { - Skilled people possible export product }\end{array}$ \\
\hline Weaknesses & $\begin{array}{ll}\text { - } & \text { Basic education poor } \\
\text { - } & \text { No IT literacy } \\
\text { - } & \text { Low literacy } \\
\text { - } & \text { Different languages } \\
\text { - } & \text { sublic acceptance of } \\
\text { - } & \text { Skill shortage models } \\
\end{array}$ \\
\hline Opportunities & $\begin{array}{ll} & \text { Employment increases } \\
\text { - } & \text { Education system improve } \\
\text { - } & \text { People leam structural job } \\
\text { - } & \text { Promotion of intemet } \\
\text { - } & \text { Better healthcare }\end{array}$ \\
\hline Threats & $\begin{array}{ll}\text { - } & \text { Brain drain IT skilled people after training } \\
\text { - } & \text { Resistance of people } \\
\text { - } & \text { Digital divide } \\
\text { - } & \text { Privacy }\end{array}$ \\
\hline
\end{tabular}


websites included all types of data about the structure of the organization, details of contacts, publications and reports, vision and objectives statements of the individual government departments.

- $\quad$ Online interaction: The major development of the Internet in Iraq has had a significant impact on the enhancement of communication channels between governmental organizations and citizens. The main objective of this stage is to activate the electronic participation of citizens in managing governmental organizations through the departments of electronic complaints and the gradual transformation to provide all government services electronically.

\section{ICT Impact on E-Governance}

Information and Communication Technology (ICT) do a serious role in the rapidity of the data flow among the government and people and transforming the method in which governmental organizations and citizens work together. ${ }^{15,16}$

The change from the traditional environment to the electronic environment has faced many obstacles, but citizens have gradually agreed because of the large spread of information and communication technologies. Therefore, the main role of these technologies in governance can be as follows ${ }^{7}$ :

- $\quad$ The improving of the products and services quality provided by the governmental organizations lately.

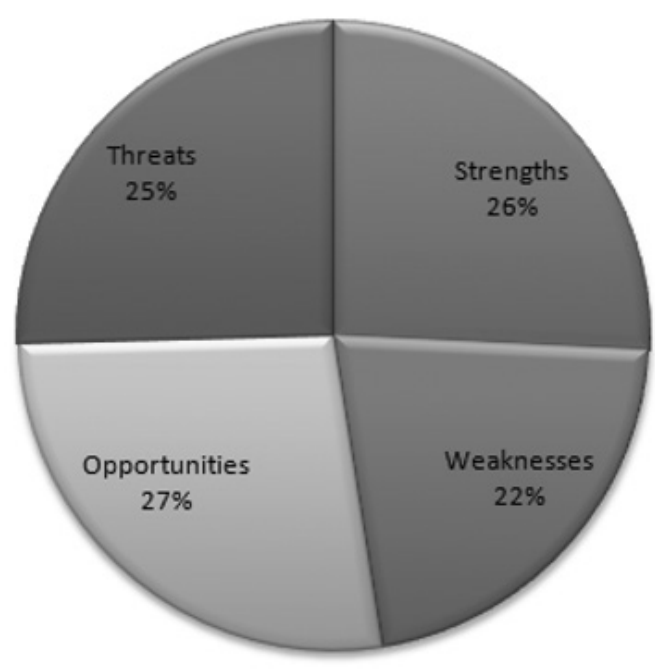

Fig. 1: The Analyzing of SWOT

Table 3: The Analyzing of the Economic Aspect by SWOT

\begin{tabular}{|c|c|}
\hline Strengths & $\begin{array}{l}\text { - E-Govemance good argument for extemal } \\
\text { funding } \\
\text { - Transparency for businesses }\end{array}$ \\
\hline Weaknesses & $\begin{array}{ll} & \text { Investors } \\
\text { - } & \text { Budget control }\end{array}$ \\
\hline Opportunities & $\begin{array}{l}\text { - Cost efficiency through e-govemance } \\
\text { - New business } \\
\text { - More efficiency tax revenues }\end{array}$ \\
\hline Threats & - Comuption \\
\hline
\end{tabular}


- The appearing of new governmental organizations' products and services.

- $\quad$ The enhancing of the citizens contributions in choosing the governmental organizations' products and services

- $\quad$ The qualifying of many new governmental sectors to provide their products and services electronically

\section{E-Governance Challenges}

Many challenges and obstacles are appeared in adopting e-governance in developing countries; the researchers summarized the main challenges in four aspects, which can be shown as follows ${ }^{8,9}$ :

- $\quad$ The political aspect: The prepared plan and policy, rules and laws, management, the processes of making a decision, the conditions of funding, the international affairs, and the political stability conditions.

- The social aspect: The citizen's education level, the type of employment, the amount of income, the size of the digital divide, the place of citizens (rural or cities), the level of citizens (rich or poor), literacy, and the IT skills of citizens.

- The economic aspect: The amount and

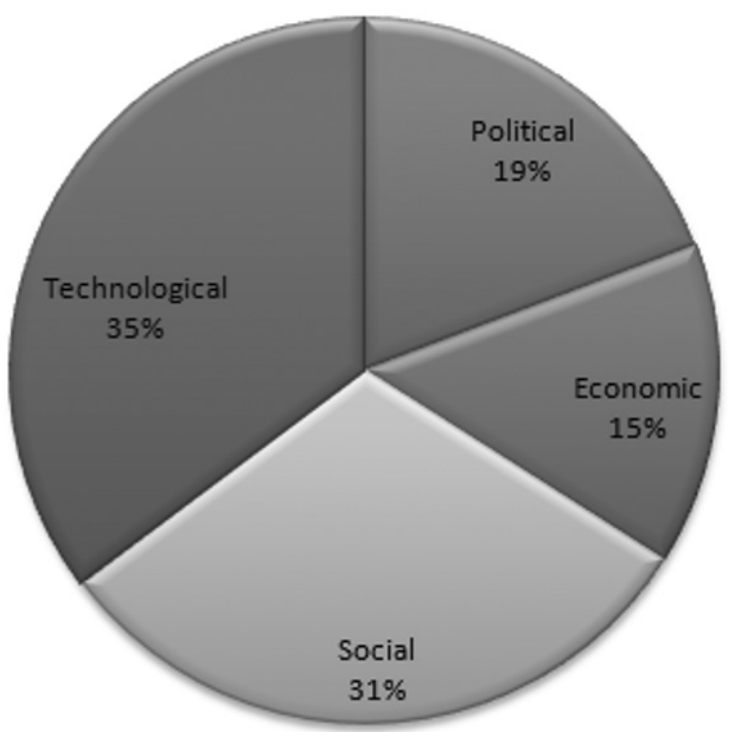

Fig. 2: The Analyzing of PEST

Table 4: The Analyzing of the Technological Aspect by SWOT

\begin{tabular}{|c|c|}
\hline Strengths & $\begin{array}{l}\text { - } \\
\text { - Lverything is new } \\
\text { - Intemet as driving (pull) factor } \\
\text { - Lack of IT standards }\end{array}$ \\
\hline Weaknesses & $\begin{array}{l}\text { - } \quad \text { Shortage IT skilled people } \\
\text { - High cost of intemet } \\
\text { - Heterogeneous data } \\
\text { - Lack of IT standards } \\
\text { - Costs of software licenses }\end{array}$ \\
\hline Opportunities & $\begin{array}{l}\text { - 2nd hand hardware available } \\
\text { - Use one standard }\end{array}$ \\
\hline Threats & - Dependency of technology \\
\hline
\end{tabular}


source of funding, the savings of cost, the models of business, the electronic commerce level in the area, and incidental results of adopting e-governance.

- The technological aspect: The technologies of software and applications, the hardware devices, the technical infrastructure of institutional communication, the IT skills employees, the services of maintenance, the conditions of safety, and the issues of security.

\section{Successful Factors}

Many spoilers exist in developing countries, so it is difficult to identify the main obstacles to position the essential aspects of e-governance in the right place. Therefore, if the plans and polices of e-governance of governmental organizations do well, all the actions, services, operations and activities of the government will do well too, but if the plans and polices of e-governance of governmental organizations don't do well, these plans and polices will cost governmental organizations huge amounts of money and valuable time. ${ }^{10,14}$

So, when discussing the risk of applying the e-governance solutions, the next factors should be taken into consideration ${ }^{11}$ :

- The stability of politics.

- $\quad$ The trust rank in government

- The significance of the governmental identity

- $\quad$ The structure of the economy

- The structure of the government

- The various levels of maturity

- $\quad$ The constituent demand

- The infrastructure of ICT

\section{Practical Part}

The challenges of adopting e-governance are analyzed by the use of SWOT to examine the organization's potential strengths and possible weaknesses in addition to the opportunities and threats, and PEST to evaluate the main four aspects.

\section{The Tools of SWOT Analysis}

SWOT is an effective analysis to recognize the potential strengths and possible weaknesses of the organization, and the opportunities and threats. So, SWOT can be a basic frame which assesses the ability of the organization logically based on internal factors (the potential strengths and possible weaknesses), and external factors (the opportunities and threats).

So, SWOT can conclude the organization assists to achieve its goals and the organization obstacles that may reduce the achievements of the goals by the use of ecological information to evaluate the organization's position. ${ }^{12,18}$

\section{The Tools of PEST Analysis}

PEST is an efficient method to deal with a lot of factors that impact on the surrounding environment of the organization. So, the organization should recognize, know and understand these factors to be able to accomplishing the performance optimally. PEST classifies effected factors to four aspects ${ }^{13,19}$ :

- $\quad$ The political aspect: Often, a government's foreign policy plays a vital role in the formulation of trade laws which can impact on the limits of trade or the motivations of trade, as well as the industry related laws can impact on the organization. So, PEST can analyze the economic involvement level of the governmental organizations, the impact of tax laws, the policies of client protection, the regulations of employment, the ecological law, and the work regulations.

- $\quad$ The economic aspect: The economic factors can impact on the organization's activities, the exchange rates can impact on the trade cost and the export volume, and the interest rates can impact on the organization's growth by its impact on the cost of the organization's capital. So, PEST can analyze the economic development indicators such as the inflation rate, the exchange rate, the interest rate, and the employment rate.

- $\quad$ The social aspect: The study of society can be helpful for organizations to understand the types of potential markets and the desires of possible clients, because the society is a main part of the external environment which surrounding the organization. So, PEST can analyze the different phases of culture, and demography such as the characteristics of career, the age rate of citizens, the growth rate of population, the degree of health awareness.

- $\quad$ The technological aspect: The rapid rate of development for the technology, and 
the increasing of citizen's knowledge in new styles of technologies lead to many challenges which can be faced by the organization. So, PEST can analyze the main technology factors such as technology modifying, research and development activities, obsolescence rate, and innovation.

\section{The Challenges of E-Governance Analyzing}

In order to analyze the four aspects of the challenges faced the adopting of e-governance in Iraq, the researchers relied on the use of SWOT.

\section{The Successful Factors of Adopting E-Governance Analyzing}

In order to analyze the successful factors of adopting e-governance, the researchers collected data from many Iraqi governmental organizations which provide their services electronically. The researchers relied on the use of SWOT and PEST to analyze the data statically. Figure (1), and figure (2) show the results

\section{Conclusion}

The researchers draw many conclusions based on the results of the paper; these conclusions are:

- $\quad$ The main needs of adopting e-governance in Iraq must start big, adopt gradually, and evaluate continuously

- $\quad$ There are many effective results to reduce the impact of the four aspects which facing the adopting of e-governance in Iraq.

- $\quad$ The opportunities for adopting e-governance in Iraq are high due to the high level of strengths over weaknesses.

- $\quad$ The success factors of adopting e-governance in Iraq can be affected strongly by the external environment.

- The political regime can be reformed by adopting the e-governance in the governmental organizations, in order to maintenance the traditional norms, and social ethics.

\section{Reference}

1. Backus, Michiel (2001). E-Governance and Developing Countries: Introduction and examples, Research report no. 3.

2. Centre of E-governance, IIM Ahmedabad, (2003). Evaluation Studies by the Centre for E-Governance, Indian Institute of Management, Ahmedabad (CEG-IIMA) Information Technology in Developing Countries, 13(1).

3. Cornforth, C. (2003). The Governance of Voluntary and Community Organizations: An Overview. Co-operatives, UK.

4. Faaeq, Munadil K., Faieq, Alaa K., Rasheed, Mohammad M., and Thabit, Thabit H. (2015). Novel Review of Electronic Government Stages among Different Continents, 7th International Conference on Information Technology, Al-Zaytoonah University of Jordan, Amman, Jordan.

5. Faaeq, Munadil K., Thabit, Thabit H., and Harjan, Sinan A. (2015). Technology Innovation Usage in Public Services Among Employees in Republic of Iraq, 7th International Conference on Information
Technology, Al-Zaytoonah University of Jordan, Amman, Jordan.

6. Retrieved from http://www.ca.iq

7. COUNCIL OF EUROPE. Retrieved from https://www.coe.int/en/web/about-us/whowe-are

8. Kumbhar, Manisha A. (2012). A critical study of implication of e-governance services for effective communication with special reference to Citizens in Pune City, Tilak Maharashtra Vidyapeeth, Pune, India.

9. Savic, Dobrica (2006). E-Governance: Theoretical foundations and practical implications, Available online at www.dobrica. savic.ca

10. Thabit, Thabit H., and Jasim, Yaser A. (2017). Applying IT in Accounting, Environment and Computer Science Studies, LAP- Lambert Academic Publisher, Germany.

11. Thabit, Thabit H., and Jasim, Yaser A. (2017). The Impact of Information Security International Standards: Enhancing the Efficiency of E-Publishing over Cloud Computing Second International Conference 
of on Communication Engineering and Computer Science, Cihan University, Erbil, Iraq.

12. Thabit, Thabit H., and Raewf, Manaf B. (2017). Applications of Fuzzy Logic in Finance Studies, LAP- Lambert Academic Publisher, Germany.

13. Thabit, Thabit H., Hadj Aissa, Sid A., and Harjan, Sinan A. (2016). The Use of Fuzzy Logic to Measure the Risks of ICT in E-Audit, Revue des Recherches Economiques, 15, 30-46

14. Thabit, Thabit H., Raewf, Manaf B., Abdulrahman, Omar T., and Younis, Saif K. (2016). The Adoption of E-commerce in SMEs A case study on a sample of Iraqi enterprises, International Journal of Latest Research in Engineering and Technology, 2(6), 38-46.
15. Thabit, Thabit. H., and Jasim, Yaser. A. (2017) The Role of Social Networks in Increasing the Activity of E-learning. In Social Media Shaping e-Publishing and Academia (pp. 35-45). Springer International Publishing.

16. UNESCO (2005). E-Governance Capacity Building Website, Available online at www. unesco.org

17. When it's time to leave the stage. Retrieved from https://iicd.org/

18. Strength, Weakness, Opportunity, and Threat (SWOT) Analysis (2019, April 17). Retrieved from https://www.investopedia.com/terms/s/ swot.asp

19. What Is PEST Analysis and Why it's Useful (2014, Aug 22). Retrieved from https:// pestleanalysis.com/what-is-pest-analysis/ 